\title{
Powder for Bladder Irrigation Dosage
}

\section{Form}

National Cancer Institute

\section{Source}

National Cancer Institute. Powder for Bladder Irrigation Dosage Form. NCI Thesaurus.

Code C149808.

Solid sterile preparation consisting of one or more powders intended to be dissolved in sterile water to obtain a bladder irrigation. 